\title{
Shifting the balance of power: civil liberties in the 21st century
}

\author{
by Geoffrey Bindman
}

The title of this piece was chosen before 11 September. The events of that day and the so-called 'war against terrorism' present new challenges to those who value civil liberties and to the rule of law, and I will come to those later.

$\mathrm{F}$ irst, I need to say a little about my own standpoint. In 1963 I started one of the first legal aid solicitors' practices in North London. While I have dabbled in all kinds of legal problems, my main interest has always been to help people achieve justice in their relations with the rich and powerful, including the state and other public authorities. So civil liberties have been a vocation. By civil liberties I mean those freedoms, which in Britain over centuries have become recognised by the law as belonging to every individual. In this article I stick to civil and political rights, broadly those listed in the European Human Rights Convention (ECHR) and the Human Rights Act: the right to freedom from arbitrary arrest, detention, torture and inhuman and degrading treatment, the right of privacy and free speech, free thought and movement, the right to a fair trial and the freedom to assemble and protest. I do not deal with economic and social rights, or environmental rights (the so-called third generation rights, important as they are) because I do not want to spend time on fine distinctions and drawing boundaries.

\section{HISTORICAL DEVELOPMENTS}

I stress the historical basis of civil liberties in Britain. Largely British Lawyers drafted the European Convention and it draws on English history. We must not throw away what has been achieved here by hard fought struggle over centuries. Let me begin with Magna Carta, the product in the year 1215 of one of the earliest protest movements. The barons who demanded concessions from King John were not representatives of the people but great landowners. Nevertheless part of their achievement was to establish minimum rights for the people against the otherwise absolute power of the state, personified in the king:
'No freeman shall be taken or imprisoned or disseised or exiled or in any way destroyed, nor will we go upon him nor will we send upon him except by the lawful judgement of his peers or the law of the land.'

Some see this as the origin of modern jury trial and indeed of the rule of law. G M Trevelyan says of it 'a process had begun which was to end in the putting the power of the Crown into the hands of the community at large.' The Great Charter had a profound influence on future generations. To quote Trevelyan again:

'The antiquarians and lawyers who asserted our

Parliamentary liberties in the age of Coke and Selden saw looming through the mists of time the gigantic figure of

Magna Carta as the goddess of English freedom...its historical importance lay not only in what the men of 1215 meant by its clauses, but in the effect it has had in the imagination of their descendants.'

The clause, which I have quoted, has a specific relevance to civil liberties. It asserted the right of the individual to freedom except where the law restricts it.

From this other principles follow. First, the presumption of innocence. The burden of proving wrongdoing or liability rests on the claimant, whether the state or a private individual. That is the basis of the writ of habeas corpus, by which the courts for centuries intervened to release anyone detained without lawful authority. In 1628 Selden described habeas corpus as 'the highest remedy in law for any man that is imprisoned' (Radzinowicz). The right against self-incrimination and the closely related right to remain silent in response to questioning by police or others in authority also follow.

The jury has had a vital role in safeguarding our civil liberties. In 1794 several leading radicals, who demanded 
reform of the electoral system in the wake of the French Revolution, were prosecuted for treason. The judge directed the jury in terms which required them to convict. The jury acquitted, as they had the right to do. In the 1980s a jury similarly cleared Clive Ponting after the judge rejected his defence under the Official Secrets Act.

It came to be accepted that civil liberty was the normal right and entitlement of all citizens. It can fairly be claimed that the principles I have mentioned acquired constitutional status, limited only where there were powerful reasons of security, which the state had to justify. The cardinal principle was that everything was lawful unless the law prohibited it. Requiring the press in earlier times to be licensed restricted free speech. Laws of sedition and libel laws also imposed restrictions. Restrictions had been imposed on religious freedom. By fits and starts most of these restraints were removed.

Later in the 19th century, however, civil liberties were under threat in Ireland where there was unrest. Parliament passed Coercion Acts to permit executive detention. Dicey described one of these as:

'in principle ...thoroughly vicious; it in effect gave the Irish executive an unlimited power of arrest; it established in them a despotic government. It could not be made permanent, and applied to the whole United Kingdom without depriving every citizen of security for his personal freedom.'

In the 1914-18 war such powers were indeed extended to the whole United Kingdom. The Defence of the Realm Act allowed detention of those suspected of aiding the enemy. They became liable to arrest and unlimited detention on the authority of the Home Secretary. The powers taken in the First World War were removed thereafter, but they were relied on as a model when war threatened again in the 1930s. An anxious government introduced similar measures, exemplified by the notorious regulation 18B. As Professor Brian Simpson has shown, this measure was initiated with no regard to civil liberty whatsoever. It was designed by the then officials of the Home Office to confer absolute power on the Secretary of State to detain without charge or trial anyone who in his opinion needed to be prevented from acting in any manner prejudicial to the public safety.

The first draft used this language. Professor Simpson says that 'this draft expressed the spirit of arrogant selfconfidence, which as a consequence of the vast extension of bureaucratic power during the first war, had come to infect the higher Civil Service.' The Secretary of State was given power to detain where he had reasonable cause to believe a person to be of hostile origins or associations or to have been recently concerned in acts prejudicial to the public safety or the defence of the realm. The eventual scheme incorporated some safeguards. The reason for detention had to be set out in writing and the detainee was given the right to make representations to an advisory committee which could supply further particulars of the reasons for detention and could recommend release. But the intention of those advising the government, as documented by Brian Simpson, was to exclude judicial review.

Jack Perlsweig was a Jew who had changed his name to Robert Liversidge. Doubtless he did so as many Jews at the time did in order to avoid anti-semitism. He had been a successful businessman and on the outbreak of war volunteered for the RAF where he became an officer. Apparently because he had applied in a name not his original one, and because he had some unsavoury acquaintances in his business life, he was detained under regulation 18 (b). It is absolutely plain now that he was not a threat to security in any way. Liversidge challenged his detention in the courts up to the House of Lords, who decided they were powerless to intervene. They held that the reasonableness of the Home Secretary's belief was a matter for him and not for the courts. Lord Atkin famously and eloquently dissented, accusing his colleagues of failing in their duty to protect the liberty of the citizen against the arbitrary action of government. I quote one well-known passage, which resonates today:

'In this country, among the clash of arms, the laws are not silent. They may be changed but they speak the same language in war as in peace. It has always been one of the pillars of freedom, one of the principles of liberty for which on recent authority we are now fighting, that the judges are no respecters of persons and stand between the subject and any attempted encroachments on his liberty by the executive, alert to see that any coercive action is justified in law.'

Many people were detained under regulation 18(b) for no good reason and often in poor conditions. Abrogating traditional safeguards led to abuses and injustice and, according to Brian Simpson, with no effect whatsoever on the war. Hundreds suffered in vain. In 1944 Winston Churchill approved the release by Herbert Morrison of Oswald Mosley on health grounds. He cabled Morrison as follows:
'You might consider whether you should not unfold as a background the great privilege of habeas corpus and trial by jury, which are the supreme protection invented by the English people for ordinary individuals against the state. The power of the executive to cast any man into prison without formulating any charge known to the law, and particularly to deny him the judgment of his peers, is in the highest degree odious and is the foundation of all totalitarian government... Nothing is more abhorrent than to imprison a person or keep him in prison because he is unpopular. This is really the test of civilisation.'

In more recent years Atkin's view has received greater approval than the majority view, at any rate outside Britain. A few brave South African judges during the apartheid regime struck down ministerial rulings made under similar regulations. However, in Britain the judges have continued 
to show reluctance to intervene. In 1977, Lord Denning said in the case of Hosenball:

'There is a conflict between the interests of national security on the one hand and the freedom of the individual on the other. The balance between these two is not for a court of law. It is for the Home Secretary. He is the person entrusted by Parliament with the task. In some parts of the world national security has been used as an excuse for all sorts of infringements of individual liberty. But not in England.'

This is astonishingly complacent, but not untypical of the time.

\section{CIVIL LIBERTIES IN THE TWENTIETH CENTURY}

I have taken rather a long time to reach the present century. I believe the history which I have recounted is important because it demonstrates a long, proud certainly unique legal framework for guaranteeing the protection of civil liberties. There have been fluctuations in the effectiveness of that protection, but by and large it has helped to discourage arbitrary deprivation of liberty even in modern times. The independence of the judges and their capacity and willingness to maintain and apply these principles are vital issues. The problem is that they cannot easily be expected to defy Parliament even if they wish to.

Even before 11 September we had good reason to be concerned at the erosion and suppression of civil liberty by legislation. The world has become vastly more complex since Magna Carta. The volume of legislation and regulation, which impinges on civil liberties, is huge. Only in the 20th century for the first time was international agreement attempted on the identification and categorisation of fundamental rights and liberties.

The rights identified in 1950 in the ECHR became accessible to residents of the United Kingdom at least after the right of individual petition was accepted in 1966. The possibility of challenging the failure of domestic law to protect those rights proved an inadequate safeguard both because the process in Strasbourg was cumbersome, slow and expensive and because the terms of the Convention did not cover important liberties. Indeed, restrictions on civil liberties continued to be imposed. During the Thatcher period numerous inroads were made. Keith Ewing and Conor Gearty filled a whole book with examples (Freedom under Thatcher). To note a few at this stage:

- police powers were extended by the Police and Criminal Evidence Act 1984, widening powers of arrest without warrant; the right of an arrestee to legal advice was restricted by requiring the arrestee to establish a request for it;

- restrictions were made on freedom of assembly and protest, especially in relation to industrial disputes;
- tougher powers were implemented to suppress information on national security grounds by restricting the public interest defence.

In this last example I refer to the case of Clive Ponting, who disclosed information about the sinking of the Argentinian battleship Belgrano during the Falklands war to a Member of Parliament. The judge directed the jury that 'the policies of the state mean the policies laid down by the recognised organs of government and authority'. After the jury flouted that direction by acquitting Ponting, the new Official Secrets Act passed in 1989 made the defence even more restrictive. The issue is very much a live one, which the House of Lords will have a chance to review in the forthcoming Shayler appeal.

Under the present government we have seen little inclination to reverse the restrictions of the Thatcher period. On the contrary, since it took office in 1997 we have seen further restrictions. We have also seen access to legal advice and representation made more difficult by the changes which have been made to legal aid. That is a big subject, which I cannot examine in detail here.

\section{GOVERNMENT RESTRICTIONS ON CIVIL LIBERTIES}

Governments can always justify restrictions on civil liberties by the need for tough measures to stamp out or prevent crime, even though there is no evidence that any measure proposed will promote either of these objectives. Certainly there is no basis for believing that the denial of basic rights will significantly reduce crime, and if it does so it must be at the expense of the liberty of innocent people. I will not list all the acts or omissions of the present government which merit criticism, but it is worth mentioning some which were expressly criticised by the UN Human Rights Commission at the end of last year:

- The detention without charge or trial of asylum seekers. Here I would mention the successful challenge last year by some of those detained at Oakington, who complained that their detention violated Article 5 of the ECHR. The judgment of Collins $\mathrm{J}$ in my opinion was entirely logical and sound but the Court of Appeal reversed his decision, apparently holding that the convenience of the Home Office could justify deprivation of the liberty of innocent people.

- The government's failure to tackle racial incitement. This is a criticism of the failure of the government to protect the liberty of those subjected to racial harassment.

- Use of the Official Secrets Act to prevent journalists and former employees from speaking out on issues of public concern.

- Failure to set up an inquiry into state-sponsored 
murders in Northern Ireland (this refers particularly to the Finucane and Nelson cases).

- Deficiencies in anti-discrimination law.

- Failure to reconsider the removal of the right to silence by allowing adverse inferences to be drawn from a defendant's silence.

- Withholding of evidence in criminal cases by relying on Public Interest Immunity.

Other examples not raised by the UN Human Rights Committee include the powers of surveillance by police granted by the Regulation of Investigatory Powers Act 2000, the Terrorism Act, and the Anti-Terrorism Crime and Security Act 2001. I will deal with those below.

\section{THREE AREAS OF GREATEST HOPE}

This bleak picture is lightened to some degree by some measures, which have extended rights. For example, antidiscrimination law has been strengthened following the Stephen Lawrence Inquiry. The greatest hope for civil liberties is in three areas which I will now look at: the Human Rights Act; European Community Law; and International Human Rights law.

Because the Human Rights Act allows the civil liberties safeguards embodied in the Convention to be directly invoked in domestic courts, they are much more accessible and are already having a positive impact. However, that impact has been much more modest than was predicted by those who saw the HRA as a charter for troublemakers who would flood the courts with frivolous complaints. The Human Rights Project at LSE has tracked all the cases in the higher courts in which the Act has been relied on. In its recent report, covering cases up to the end of December 2001, it says:

'...it appears that the Act has been successfully pleaded much less often than was anticipated in the months before its coming into effect. Human rights points have almost always been raised in cases, which would have been taken anyway, using traditional legal grounds of challenge. In other cases, judges have found human right principles to reinforce the result reached, rather than radically alter it. There has therefore been less the forecasted legal revolution, and more the first steps in a process of subtly weaving human rights principles into the fabric of existing UK law.'

Coming down to figures, we are talking about 347 cases in all, out of which the outcome, reasoning, or procedure was affected in 247 cases. In only three cases was the domestic law declared incompatible with the rights protected by the HRA. Only 72 claims brought directly under the Human Rights Act succeeded.

One can interpret these results in different ways. A reassuring conclusion would be that our law protects civil liberties rather well, and only a few loopholes need filling. One must also remember that the Act appears to have been taken very seriously by many public authorities that have altered previously doubtful practices in order to comply with it. However, it is not obvious that the public at large is aware of its rights under the Act or knows how to lodge a complaint. The government has resisted calls for a Human Rights Commission which could educate and advise the public and could help to filter and target issues which ought to be decided in the public interest. The United Nations Human Rights Committee at the end of last year criticised the UK government for failing to set up such a Commission. The claim by the Human Rights Project that most of the cases raising human rights issues would have been brought anyway highlights concern that there may be obstacles to raising novel questions.

An obvious difficulty is funding. The ability of those without substantial means suffers from the changes in legal aid, which I have mentioned. Also, it appears that the priority funding for human rights cases, which, was announced by the Lord Chancellor after the Act became law has rarely, if ever, been called upon.

Other shortcomings, which limit the effectiveness of the Human Rights Act as a safeguard for civil liberties, are to be found in the Convention itself. Although it originated in the English civil liberties tradition described earlier, it has important gaps. For example, the right to a fair trial does not include the right to trial by jury - doubtless because juries are not used in continental legal systems. Furthermore, it fails to reflect human rights issues that have become major concerns since 1950. Social and political rights are completely absent, including employment rights. Discrimination is prohibited only when incidental to other rights. There are also signs of growing unwillingness of the Court of Human Rights to interfere with what is perceived as acceptable to governments in general. In the recent case of Al-Adsani the court, admittedly by the narrowest possible majority, rejected a claim under Article 6 that state immunity was incompatible with the right to a fair trial, even where the claimant alleged torture. The doctrine of 'margin of appreciation' allows the court to abstain from politically sensitive issues.

A right to be free from discrimination on racial and other grounds will be added to the Convention by the 12th protocol, now in draft. Meanwhile, some protection against gender discrimination is provided by European Community law, which, unlike the ECHR has long been directly enforceable within domestic courts. Cases taken to the European Court of Justice have strengthened antidiscrimination law by, for example, removing the limit on the level of compensation, which can be awarded in discrimination cases, and by ending sexual orientation discrimination in the armed forces. As a result of Article 13 of the Treaty of Amsterdam, the legislative powers of the European Commission are extended to other forms of discrimination and a Directive prohibiting employment and 
other discrimination will soon be in force. Time does not allow a fuller exploration of the complexities of European law on discrimination. Suffice it to say that in the next few years it will extend protection from discrimination beyond the current domestic categories of race, gender and disability.

European community law also has an impact on civil liberties in other areas, particularly immigration and asylum, and in the extension of police powers across national boundaries. In these areas the effect has not been to extend but to weaken protection of civil liberties. The excellent magazine Statewatch, which describes its objective as 'monitoring the state and civil liberties in the UK and Europe', has documented for some years the proliferation of legislation in the European Union and its Member States designed to promote co-operation between police and other authorities in criminal investigation and immigration control. That co-operation includes the exchange of information and sharing the results of surveillance. Statewatch has constantly warned against the lack of access to information about these arrangements and the absence of democratic control within the European institutions. Recent proposals for simplifying extradition between European states and for a European arrest warrant which will enable suspects to be transported across national borders pose great dangers. Inevitably they weaken the capacity of those deprived of liberty to mount any effective challenge.

There have been some positive developments in international human rights law, which increase the prospects for bringing to justice those in positions of power who abuse human rights and who commit crimes against humanity. The forthcoming establishment of the International Criminal Court and the trend towards universal jurisdiction over crimes against humanity may prove to be an effective vehicle for the prosecution of those major international criminals who at present can travel about the world without fear of retribution. We have also seen in operation the war crimes tribunals for Rwanda and the former Yugoslavia. Though slow and under-resourced, they have been the means of bringing to trial major criminals who would not have faced justice in their own countries.

\section{ISSUE OF TERRORISM}

Now at last I come to the issue of terrorism, not unknown before 11 September. The threats by government to civil liberties which I have referred to so far have all been in train before 11 September, but the socalled 'war against terrorism' is being used, and will continue to be used, to justify repressive and coercive measures which even before that momentous date might have seemed unacceptable.

The Terrorism Act 2000 came into force on 10 February 2001. It was partly designed to consolidate existing legislation, including the Prevention of Terrorism Act. The latter was temporary and renewable, and was limited to terrorism in Northern Ireland. The new Act widened the definition of terrorism and authorised the Home Secretary to proscribe organisations believed by him to engage in or advocate terrorism and made it a criminal offence to be a member of such an organisation or to support it without being a member. The funds of such organisations were liable to be frozen or forfeited. Participation in a meeting of three or more people to support or further the activities of such an organisation became a criminal offence. An appeal against proscription can be made to a Prescribed Organisations Appeal Commission, and judicial review may be available, but it remains uncertain that a court could ever investigate the facts on which the Home Secretary bases his decision to proscribe and quash it (shades of Liversidge and Anderson). I was asked to advise a proscribed organisation and we consulted counsel. We realised at our consultation -at which five people were present - that we were unwittingly committing an offence. We wrote to the Attorney General to ask him not to prosecute us. He kindly said he would not do so.

No one denies the seriousness of the threat of terrorist violence and stern measures are justified to deter and indeed punish those guilty of terrorist offences. But is it really necessary to violate fundamental liberties to do so? History may not be a totally reliable guide because technological sophistication poses unprecedented challenges. But reliance on the unsupported opinion of police and security personnel has failed us many times - I have already talked about regulation $18 \mathrm{~B}$ in the Second World War - and produced many miscarriages of justice.

The saddest blow to civil liberties in Britain has been the government's derogation from Article 5 of the European Human Rights Convention and from the equivalent provision in the International Covenant on Civil and Political Rights to validate detention without charge or trial of suspected international terrorists under section 23 of the Anti-Terrorism, Crime and Security Act 2001. The detention can last as long as such a person cannot be deported or removed to another country, in other words for life. To detain an innocent person indefinitely on the basis of mere suspicion cannot be justified. The possibility of challenge under the Human Rights Act remains of course both as to the validity of the law and in any individual case which might arise, but in the current atmosphere one cannot be optimistic that any such claim would succeed. Nor do the 'sunset clauses' in the Act give much comfort. History tells us that restrictions on liberty once enacted usually remain.

Under the present government police powers have been extended in many ways. There has been a plethora of complex legislation since 1997 adding to the powers of government to invade the privacy of the citizen. Among such legislation is the Regulation of Investigatory Powers Act 
2000, (which coincidentally came into force on the same day as the Human Rights Act), the Terrorism Act 2000 which I have referred to, the Criminal Justice and Police Act 2001, and the Anti-Terrorism, Crime and Security Act 2001. Trial by jury has been threatened and, following the Auld report, is still under threat.

\section{PROSPECTS FOR CIVIL LIBERTIES}

So, to conclude, what are the prospects for civil liberties in the present century? On the positive side there are the ECHR and the Human Rights Act. The Act will be provide continuing opportunities for challenging the attacks on civil liberties but the deficiencies I have described are likely to remain and there seems no early prospect of a distinct British Bill of Rights which may be the only way of modernising human rights safeguards.

On the negative side is the insecurity of governments, which encourages them to secretive, heavy-handed and repressive use of their power. That insecurity is naturally intensified by the events of 11 September and the widespread belief in a worldwide terrorist network capable of unpredictable and devastating violence. In the face of such fear, faith in civil liberties is weakened among many and to defend them becomes more difficult and more unpopular. We are seeing a distressing illustration in the USA, where civil liberties have the most powerful legal safeguards. There is mass support there for attempts by the government to circumvent those safeguards by taking prisoners outside the jurisdiction, where they are held without charge or trial, or access to lawyers, and in defiance of the Geneva Conventions. In Britain we have not yet gone down the same road.

In between the state and the individual the judges have a difficult role. Many deserve credit for their fearlessly principled willingness to stand up to government where civil liberties are in jeopardy. There is respectable support for the view that the judges' constitutional role as the protectors of fundamental rights transcend parliamentary sovereignty. I refer to the remarks of Lord Justice Laws in the case of Witham, which he has elaborated in lectures. But a battle between the judiciary and Parliament seems unlikely. In the last resort only the people themselves can defend their liberties. Whether they will succeed in doing so remains to be seen. In short, to conclude with a wellworn expression, which, I hope will never become obsolete, the jury is still out.

Geoffrey Bindman

Bindman \& Partners

This article is based on a leture given at the IALS on 21 February 2002.

\title{
The Law Society and the Bar: can they be trade unions,
} brand managers and public watchdogs at the same time?

\author{
by David Lock
}

The author reflects on the way lawyers are regulated and considers whether, in the long run, it is in the public interest for the present system of regulation by professional bodies to be continued in its present form.

$\mathrm{T}$ he question as to whether professionals can be trusted to regulate themselves in the public interest has come into sharp focus with the collapse of Enron and the allegations - to date unproved - of collusion by the auditors, Arthur Andersen. Hundreds of millions of dollars have been spent in the US lobbying the senate over decades to preserve the right of self-regulation for accountants, only to find that the unwise and unauthorised shredding of documents by Andersen's appears to have fundamentally undermined public confidence in the concept of self-regulation. 